\title{
English Reading Anxiety in Relation to the Oral Reading Fluency of Grade 11 Students
}

\author{
Jane Charity Estrada-Madronero ${ }^{1}$ \\ ${ }^{1}$ Ozamiz City National High School, Ozamiz City, Philippines \\ Correspondence: Jane Charity Estrada-Madronero, Ozamiz City National High School, Ozamiz City, Philippines
}

Received: October 9, 2018; Accepted: November 17, 2018; Published: March 30, 2019

\begin{abstract}
Reading is an essential skill that students need to develop. However, readers may experience anxiety in reading materials in English. This study determined the level of English reading anxiety in relation to the oral reading fluency of the 163 Grade 11 students of Ozamiz City National High School, Ozamiz City. A descriptivecorrelational design was used in the study. Adopted English Reading Anxiety Questionnaire and a Multidimensional Fluency Scale for Oral Reading Fluency were used in gathering the data. Mean, Standard Deviation, and Regression Analysis were the statistical tools used in analyzing the data gathered. Results revealed that the level of English reading anxiety of the respondents was high, and their level of oral reading fluency was instructional. There was a highly significant relationship between the English reading anxiety and the oral reading fluency of the students. Anxiety affects how well students read materials in English.
\end{abstract}

Keywords: anxiety, fluency, instructional level, reading, skill

\section{Introduction}

Reading is very significant in second language learning. It improves a learner's literacy (Urquhart \& Weir, 2014). It is essential to learn to read in English fluently as it is the primary language of business, government, education, news, and information in the world (Navarro, Garbin, Agena, \& Garcia, 2015). Moreover, the ability to read and interpret textbooks and other assigned material is a critical component of success in university, and in everyday life (Ntereke \& Ramoroka, 2017) as reading is used to meet practical, personal, social, socio-civic demands of daily living (Estrada, 2016).

To some adults, reading seems so effortless and automatic that it is often assumed as a natural skill for anyone to acquire (Sousa, 2014). However, second language reading is difficult (Cheng-Hsien Han, Chi-Lan Yang, \& HaoChuan Wang, 2014). In most cases, students with reading difficulties in English are not able to read according to their grade, and they feel even more anxious and depressed because they are not able to perform like their other classmates (Sabti et al., 2016). Consequently, non-fluent readers and those with reading difficulties are reported to be involved in bullying - either victims or bullies (Salmavelli, 2017).

Since reading is an inherently effortful activity that requires focused attention and concentration, affective variables significantly influence reading processes (Hayashi, 2015). These affective variables include attitudes, motivation, language anxiety, personality and learning style (Al-Shboul, Ahmad, Nordin, \& Rahman, 2013). Among these affective factors, anxiety is the most potent predictor of the students' reading performance (Liu \& Huang, 2011; Huang, 2012; Subasi, 2016).

Reading anxiety is a situational phobia that is characterized by an unpleasant, disturbing emotional reaction experienced by students when reading (Piccolo et al., 2017). Specifically, foreign language reading anxiety pertains to the feeling of apprehension and worry when students have to read in a non-native language like English (Rajab et al., 2012). It makes one feel challenging to concentrate, to remember the ideas, and to learn anything new (Huang, 2012). As a reaction developed against reading, foreign language reading anxiety can manifest itself not only in situations in which reading is required such as a classroom reading activity or an exam but also as abstinence from reading (Melanlioglu, 2014).

Reading anxiety in English distracts or hinders fast cognitive reading processing among second or foreign language speakers (Huang, 2012). It results to poor reading performance while non-anxious learners may be less bothered by task-irrelevant thought; therefore, they may have more attention and capacity contributing to the process of 
reading fluency and comprehension (Mohammadpur \& Ghafournia, 2015). Worse, reading anxiety could inhibit not only understanding but the acquisition of the second language (Rajab et al., 2012).

Several studies concerning the causes of anxiety have been conducted. Anxiety can be caused by the reader himself as he is afraid of making errors and worry about reading effects (Muhlis, 2017). It can also be caused by textual factors such that of unknown vocabulary, unfamiliar topic, and foreign culture (Al-Shboul, Ahmad, Nordin, \& Rahman, 2013). More importantly, the first source of reading anxiety involves the contribution of the reading environment of the child especially if it feeds negative emotions creating the phobia (Guimba \& Alico, 2015).

Foreign language reading anxiety (FLRA) negatively correlates with reading performance (Zhao, Guo \& Dynia, 2013). In a study conducted to twenty Iraqi high school students studying EFL in Malaysia, it can be gleaned that students' reading anxiety caused extreme and unsuitable stress, tension and shyness especially on superficial errors in spelling and pronouncing English words (Sabti et al., 2016).

Reading difficulty in adults links to anxiety yet it has not been systematically studied (Meer, Breznitz, \& Katzir, 2016). A small number of empirical studies have examined its effects on reading (Subasi, 2016).

Learners who have higher reading anxiety tend to have the lower reading achievement (Tsai, 2013). In a study conducted to 112 junior and senior students in Iran, it indicated that there is a significant negative relationship between FLRA and reading comprehension (Jafarigohar \& Behrooznia, 2012). In another study conducted to 100 general English course university students in the same country, there was a negative relationship between the students' reading level and reading anxiety. The more anxious and stressful the readers are, the less skillful they are in reading and in taking reading tests (Mohammadpur \& Ghafournia, 2015).

In another study that investigated second language reading anxiety of seventy-two female secondary school students, results revealed significant differences between the levels of reading anxiety reported by students relative to their general area of study (science or arts). They also claimed that language proficiency, specifically knowledge of vocabulary and grammatical rules are the sources of anxiety (Ismail, 2015). In the Philippines, a study conducted to Grade 8 students in Marawi City revealed that a significant negative relationship exists between students' reading anxiety level and reading comprehension performance (Guimba \& Alico, 2015).

\section{Objectives of the Study}

This study determined the English reading anxiety and the oral reading fluency of the Grade 11 students of Ozamiz City National High School, Ozamiz City. The specific objectives were to:

1. Determine the level of the students' English reading anxiety;

2. Assess the level of students' oral reading fluency; and

3. Explore a significant relationship between the students' English reading anxiety and oral reading fluency.

\section{Methods}

\subsection{Research Design}

This study used the descriptive-correlational design. The descriptive research aims to accurately portray the characteristics of situations, individuals, or groups and the frequency with which certain phenomena occur using statistics to describe and summarize the data. On the other hand, the correlational research explores the interrelationship among variables of interest without any intervention by the researcher (Polit \& Hungler, 2013). The design was considered appropriate in assessing the level of English reading anxiety of the students in relation to their oral reading fluency.

\subsection{Research Setting}

The research was conducted at the Senior High School Department of Ozamiz City National High School, Ozamiz City. The school is composed of one Secondary School Principal, one Senior High School assistant principal, and twenty teachers. Of the 555 senior high school students, 280 are Grade 11 students, wherein 131 are major in Academic Track while the 149 students are in TVL Track.

OCNHS was established in the year 1952 through the joint efforts of the City Officials, the Division, and the School Personnel. It occupies a part of the school area of 33,593 square meters donated by the Bernad Family through the late city mayor Hon. Fernando T. Bernad. The school which is situated in the heart of the city serves students from all walks of life. Based on land area and student population, it is considered as the biggest public secondary school in Ozamiz City. The school has earned recognition for students and teachers who won in various competitions, not only in the academics but also in the arts and sports, whether at the division, provincial, regional and even national levels. 


\subsection{Respondents}

There were 280 students enrolled in Grade 11. Using the Raosoft application, a sample of 163 students served as the actual respondents of this study identified through simple random sampling. They students are under the SHS Academic and Technical-Vocational tracks. They have completed the Junior High School but have not yet earned a secondary credential. A total of 76 Academic majors and 87 TVL majors served the respondents of the study.

\subsection{Instruments}

\section{English Reading Anxiety Questionnaire.}

It is an adopted questionnaire by Saito et al. (1999). The instrument measures a language reader's anxiety over reading difficulties in the target language, and students' perception of various aspects of reading. The instrument has twenty items scored on a 4-point Likert scale.

In determining the level of anxiety of the respondents, the following scale was used:

\begin{tabular}{llll}
\hline & Responses & Continuum & Interpretation \\
\hline 4 & Strongly Agree (SA) & $3.25-4.0$ & Very High (VH) \\
3 & Agree (A) & $2.50-3.24$ & High (H) \\
2 & Disagree (D) & $1.75-2.49$ & Low (L) \\
1 & Strongly Disagree (SD) & $1.0-1.74$ & Very Low (VL) \\
\hline
\end{tabular}

\section{Rubric for Oral Reading Fluency}

The rubric developed by Rasinski (2004) was used in assessing the students' oral reading fluency as to accuracy, expression and volume, phrasing, smoothness, and pace. The students were given the ratings of " 4 " as the highest and " 1 " as the lowest depending on the degree of fluency exhibited by the students during the oral activity conducted. The highest score which the respondents could obtain was sixteen.

In analyzing respondents' oral reading fluency, the following continuum was used:

\begin{tabular}{llll}
\hline & Scores & Continuum & Interpretation \\
\hline 4 & Very High (VH) & $3.25-4.0$ & Very Fluent (VF) \\
3 & High (H) & $2.50-3.24$ & Fluent (Ft) \\
2 & Low (L) & $1.75-2.49$ & Fair (F) \\
1 & Very Low (VL) & $1.0-1.74$ & Poor (P) \\
\hline
\end{tabular}

In interpreting the over-all oral reading fluency, the grand score was used and analyzed using the following continuum:

\begin{tabular}{ll}
\hline Continuum & Interpretation \\
\hline $12.01-16.00$ & Independent level \\
$8.01-12.00$ & Instructional level \\
$4.00-8.00$ & Frustration level \\
\hline
\end{tabular}

\subsection{Data Collection}

Before the gathering of data started, approval for the conduct of the study was sought from the Dean of the Graduate School of Misamis University. Similarly, permission was sought from the Schools Division Superintendent of Ozamiz City and from the Principal of Ozamiz City National High School. After the approval was obtained, the instrument on Foreign Language Reading Anxiety Questionnaire was administered to the respondents. Afterward, the oral reading activity for the respondents followed. The respondents were called individually in a designated room. Each respondent understood the facets on the rubric before reading orally a text for Grade 11. The reading material was taken from the Reading and Writing textbook for Senior High School. The Flesch Reading Ease Readability Formula was utilized in determining the reading level of the text. Its reading ease, accuracy, and appropriateness regarding the year level were: Flesch-Kincaid reading ease $-55.8 \%$ and the grade level - Grade 11.

The researcher and two other English teachers rated the oral reading fluency of each student by using the Multidimensional Fluency Rubric developed by Rasinski (2004). One of the two co- raters is a Master Teacher I handling subjects in the Senior High School while the other is a Teacher III and is teaching Reading and Writing and other core subjects in Grade 11. The former is a holder of master's degree in English while the latter is currently 
finishing her master's degree in English at La Salle University, Ozamiz City. They were both oriented on the nature of the study and the research instruments utilized.

All data were tallied using the Microsoft Excel application and were subjected to statistical computations using the Minitab Software.

\subsection{Ethical Consideration}

The ten principles of ethical considerations by Bryman and Bell (2007) were complied with in this study. First, the research respondents were not subjected to harm. Respect for the respondents' dignity was prioritized. Full consent was obtained from the students and their parents before the study. Protection of the privacy of research respondents, an adequate level of confidentiality of the research data, and the anonymity of individuals participating in the research were ensured. Moreover, deception and exaggeration about the aims and objectives of the research were also avoided. Affiliations in any forms, sources of funding, as well as any possible conflicts of interest, were declared. Lastly, any communication concerning the research was done with honesty and transparency and any misleading information and representation of primary data findings in a biased way were avoided.

\subsection{Data Analysis}

The study used the following statistical tools in analyzing the data gathered:

Mean and Standard Deviation. These were used in determining the level of the English reading anxiety and the oral reading fluency level among the respondents.

Regression analysis and Pearson Product Moment Correlation Coefficient. These were used in exploring the significant relationship between the respondents' English speaking anxiety and oral reading fluency.

\section{Results and Discussion}

\subsection{Level of Students' English Reading Anxiety}

The level of students' English reading anxiety was high as evidenced by the Mean of 2.53 (Table 3). This result was based on the perception of the respondents toward reading instructional materials in English. This implies that the students felt a deep level of discomfort or tension whenever they were asked to read in English.

The English subject requires students to read various texts written in English and to deliver reading activities using the target language. However, several reading teachers have observed that students struggle through avoidance or refusal to read. These students experience sweating and difficulty in producing the proper intonation and rhythm of the language, distortion of sounds, handshaking, weakening of some body parts, freezing up when called to read, or worse, opt to keep silent. Despite encouragement from teachers, some students insist that they are not good in English and that they refuse to read texts using the language.

In the context of real language use, it is normal for second language learners to feel stress especially if they are still young (Piccolo et al., 2017; Rasinski, 2014). On the contrary, the high level of anxiety among Grade 11 students is entirely a surprise especially as in the Philippine classrooms; students are exposed to the target language as early as their elementary grades. English has been the medium of instruction in most subjects. In relation to this, a study reported that 16 to 18 years old high school Iraqi foreign language learners also have a high level of anxiety towards reading in English. It is the result of extreme and inappropriate stress, shyness, and tension on superficial errors in reading and pronouncing English words (Sabti et al., 2016). Similarly, a study disclosed that students can be anxious caused by personal reasons, teacher's manners in the classroom, teaching procedures used in class, features of reading texts, reading test anxiety, and their previous experience (Subasi, 2016). Also, foreign language reading does provoke anxiety among foreign language learners who are non-English majors in college (Huang, 2012).

Becoming a confident reader in English requires an ample investment of time and effort. Hence, classrooms need to be physically and psychologically conducive to the development of reading skills where teachers assure their students that committing errors is part of the learning process and that the feeling of nervousness is natural and should not be considered a hindrance to not reading English texts well.

Table 1. Descriptive Statistics on the Level of Students' English Reading Anxiety ( $\mathrm{n}=163$ )

\begin{tabular}{lcc}
\hline Construct & Mean & StDev \\
\hline Anxiety level & 2.53 & 0.34 \\
\hline Scale: $3.25-4.0$ (Very High); & 2.50-3.24 (High); 1.75-2.49 (Low); $1.00-1.74$ (Very Low) &
\end{tabular}




\subsection{Level of Students' Oral Reading Fluency}

The overall level of the respondents' oral reading fluency is instructional $(\mathrm{M}=10.85 ; \mathrm{SD}=3.04)$ as seen in Table 2. This result means that on average, the respondents have a fluent reading level concerning the accuracy, expression, and volume, phrasing, smoothness, and pace.

Concerning accuracy, phrasing, smoothness, and pace, the respondents are fluent. This finding reflects the effectiveness done by their present and past reading teachers in molding them to become able readers who need less scaffolding. The text for them may be challenging but manageable. They were able to read with $86-90$ percent precision even though there were several times for some students that they had to stop out of confusion on how to read words correctly. They managed to orally decode with a mixture of moderately fast and slow pacing, and with good prosody or expression.

Challenges with fluent reading extend into the middle and secondary grades. This claim loomed as a result of their study in 2011 that assessed 108 ninth-grade students attending an urban high school were two years behind on grade-level norms of reading with accuracy and pace (Paige \& Magpuri-Lavell, 2014).

Table 2 shows the level of accuracy, expression, and volume among readers $(\mathrm{M}=2.74 ; \mathrm{SD}=0.82)$. The respondents are fluent in this aspect. The results prove that on average, the learners can read with only $1-10$ percent errors. In some areas of the passage, they make the text sound like natural language. Voice volume is appropriate although they occasionally slip into expressionless reading.

Moreover, the results of the current study disclosed that the level of oral fluency concerning phrasing and smoothness is fluent, as supported by the Means of 2.79 and 2.72, respectively. These findings mean that learners can read with a mixture of run-ons, mid-sentence. They pause for breath. There is some choppiness in their reading. There are reasonable stress and intonation. Poor decoders among children and adults have been shown to pause inappropriately more than good decoders and to exhibit less pitch variation (Schwanenflugel et al., 2015). The respondents, therefore, are good decoders of the text read although some also experienced occasional breaks because of difficulties with some specific unfamiliar words.

Lastly, their level of fluency concerning pacing is also fluent $(\mathrm{M}=2.82)$. Some respondents read at a moderately slow pace, but majority read with a mixture of fast and slow pace. Although on average the students reached the instructional level of overall reading fluency, teachers need to look into those students who are at the frustration level. Teachers need to foster a classroom that promotes love for oral reading and fluency in reading any types of text to develop critical reading and prepare them for further education or future work. They must also be exposed to relevant oral reading activities to make them grow into independent readers.

Table 2. Descriptive Statistics on the Level of Students' Oral Reading Fluency

\begin{tabular}{lll}
\hline Constructs & Mean & StDev \\
\hline Accuracy & 2.74 & 0.82 \\
Phrasing & 2.79 & 0.81 \\
Smoothness & 2.72 & 0.80 \\
Pace & 2.87 & 0.83 \\
Overall reading fluency & 10.85 & 3.04 \\
\hline
\end{tabular}

Fluency Scale: 3. 25-4.0(Very fluent); 2.50-3.24(Fluent); 1.75-2.49(Fair); 1.00-1.74 (Poor)

Overall Fluency Scale: 12.01-16.0(Independent level); 8.01-12.0 (Instructional); 4.0-8.0 (Fair)

\subsection{Significant Relationship between the Level of Students' Reading}

\section{Anxiety and Oral Reading Fluency}

The data in Table 3 shows the results of the regression analysis using anxiety as a predictor of the students' oral reading fluency. It revealed a highly significant relationship between the two variables. The regression coefficients for accuracy, expression, and volume, phrasing, smoothness, and pace are $-0.263,-0.279,-0.359$, and -0.323 , respectively (Table 3 ). The coefficients are negative and show an inverse relationship between anxiety and the four components of oral reading fluency.

The results indicated that oral reading fluency regarding accuracy, expression, and volume, phrasing, smoothness, and pace were influenced by the level of students' English reading anxiety. The less anxious the students were, the better was their reading fluency. On the contrary, the higher the anxiety level of the students was, the lower 
the level was their oral reading fluency. In relation to this, students who experience a high level of anxiety may perceive a second language learning situation as frightening and intimidating and may respond to this threatening situation by showing poor learning performance (Budin, 2014).

Classroom activities in the Senior High School involve critical reading among students. However, this skill can only be mastered when students can independently read grade-level texts as is expected from them. More so, there are students who do not have the confidence even to read fluently especially when they are not sure if they understand what they are reading or when they get so confused, intimidated and bothered in pronouncing the words in English. Others get nervous when they do not understand the words and worse, get upset whenever they encounter unknown grammar when reading in English. Others also do not feel very comfortable at reading aloud and are not satisfied with their level of reading ability in English. Some are tensed at the thought that they will be listened to by their classmates and teachers using the second language. When students mispronounce words in English, the listening audience (e.g., classmates) tend to laugh, thereby causing embarrassment and loss of selfesteem of the ones trying to read. Worse, when teachers give unnecessary comments and ridicule, this may increase the students' anxiety level. Undesirable experiences may cause avoidance or refusal to avoid similar negative experience.

Relative to the findings in this study, the research on "A Study on Foreign Language Classroom Anxiety and Foreign Language Reading Anxiety among Indian ESL Learners" showed a negative correlation between foreign language reading anxiety and reading performance among participants (Mathew, 2015). Another study indicated that students who have higher anxiety level tend to have lower achievement in reading (Tsai, 2013). Higher anxiety affects comprehension, thus lowering the quality of oral reading fluency (Baki, 2017). Foreign language reading anxiety seems to be related to the perceived difficulty level of reading materials and reading task types (Sari, 2017).

Reading classrooms should be an avenue where students feel at ease as they try to enhance their fluency levels. Learners must be encouraged to read with texts that interest them and be helped in overcoming a disturbing feeling of anxiety. English teachers must be open to listening to their students and give constructive corrections or comments in a way that would not discourage or embarrass students. With thorough practice and extensive reading, the students eventually gain better oral reading fluency in English as they overcome their feeling of anxiety.

Table 3. Test of significant relationship between the level of students' English reading anxiety and oral reading fluency (ORF)

\begin{tabular}{llll}
\hline \multirow{2}{*}{ Variables } & \multicolumn{2}{l}{ Test Statistics } & \multirow{2}{*}{ Remarks } \\
\cline { 2 - 5 } & $r$-value & $\mathrm{p}$-value & \\
\hline Reading Anxiety vs Accuracy & -0.263 & 0.001 & Highly significant \\
Reading Anxiety vs Phrasing & -0.279 & 0.000 & Highly significant \\
Reading Anxiety vs Smoothness & -0.359 & 0.000 & Highly significant \\
Reading Anxiety vs Pace & -0.323 & 0.000 & Highly significant \\
Reading Anxiety vs ORF & -0.323 & 0.000 & Highly significant \\
\hline
\end{tabular}

Note $: p \leq 0.01$ Highly Significant at $\alpha=0.01$ level

\section{Conclusion And Recommendations}

Heightened discomfort and tension rise when students read written texts in English. Also, despite the length of studying and being exposed to the English language since the completion of their elementary and Junior High School, students have not gained the desirable level of oral reading fluency for their grade and age - the independent reading fluency. Moreover, the quality of the oral reading of students is relative to how they feel during the actual read-aloud task. Stress, worry, fear, or nervousness affects the oral reading using the English language. Anxiety determines a student's reading fluency.

Based on the findings and conclusions of the study, it is recommended that principals or school heads and reading teachers plan programs and activities designed to improve the students' reading fluency. Teachers give utmost priority on securing a learning environment that is free from tension and anxiety. Teachers have to create a psychologically conducive reading classroom, maintaining a relaxing atmosphere where learners feel valued, interested, joyful and motivated to learn and read more. As facilitators of learning, teachers provide a classroom that is supportive, warm, and friendly where non-threatening and non-embarrassing reading activities are applied, and non-intimidating texts are utilized. Students control their anxiety and practice reading to achieve the 
independent level of oral reading fluency. Future researchers delve into the other factors that contribute to the oral reading fluency students.

\section{References}

Al-Shboul, M. M., Ahmad, I. S., Nordin, M. S., \& Rahman, Z. A. (2013). Foreign language reading anxiety in a Jordanian EFL context: A qualitative study. English Language Teaching, 6(6), 38. Retrieved August 6, 2017 from https://goo.gl/ZXnYqG

Baki, Y. (2017). The effect of anxiety and attitudes of secondary school students towards reading on their reading habits: A structural equation modeling. Egitim Ve Bilim, 42(191). Retrieved February 10, 2018 from https://goo.gl/3xupKN

Budin, M. (2014). Investigating the relationship between English language anxiety and the achievement of school based oral English test among Malaysian Form Four students. International Journal of Learning, Teaching and Educational Research, 2(1). Retrieved February 11, 2018 from http://goo.gl/rHgMbK

Estrada, J. C. A. (2016). The Level of English Oral Reading Fluency among Abot-Alam Secondary Learners. World Journal of English Language, 6(3), 9.

Guimba, W. D., \& Alico, J. C. (2015). Reading anxiety and comprehension of grade 8 filipino learners. International Journal of Humanities and Social Sciences, (1). Retrieved November 3, 2017 from https://goo.gl/gzgxfL

Hayashi, C. (2015). Japanese learners' motivation for reading english (Order No. 3746062). Available from ProQuest Central. (1755656605). Retrieved on August 6, 2017 from https://goo.gl/k73pok

Huang, Q. (2012). Study on correlation of foreign language anxiety and english reading anxiety. Theory and Practice in Language Studies, 2(7), 1520-1525. Retrieved August 6, 2017 from https://goo.gl/Mv6ddV

Ismail, S. A. A. (2015). Secondary School Students' Reading Anxiety in a Second Language. English Language Teaching, 8(11), 28. Retrieved August 6, 2017 from https://goo.gl/tKddyu

Jafarigohar, M., \& Behrooznia, S. (2012). The effect of anxiety on reading comprehension among distance EFL learners. International Education Studies, 5(2), 159. Retrieved on August 6, 2017 from https://goo.gl/dpKGVU

Liu, Y. H., \& Samimy, K. K. (2012). Survey on anxiety in reading Chinese-English syntactic differences: A case of English reading anxiety in Taiwanese university students. Theory and Practice in Language Studies, 2(7), 1363. Retrieved August 6, 2017 from https://goo.gl/JK6RUy

Mathew, M. L. (2015). A study on foreign language classroom anxiety and foreign language reading anxiety among Indian ESL learners. ACADEMICIA: An International Multidisciplinary Research Journal, 5(11), 91-105. Retrieved November 3, 2017 from https://goo.gl/e5Yxv5

Meer, Y., Breznitz, Z., \& Katzir, T. (2016). Calibration of self-reports of anxiety and physiological measures of anxiety while reading in adults with and without reading disability. Dyslexia, 22(3), 267-284. Retrieved August 6, 2017 from https://goo.gl/UbQqoc

Melanlioglu, D. (2014). Determining the psychometric features of reading anxiety scale. Egitim Ve Bilim, 39(176) Retrieved August 6, 2017 from https://goo.gl/e7NkUq

Melanlioglu, D. (2014). Impact of metacognitive strategies instruction on secondary school students' reading anxieties. Egitim Ve Bilim, 39(176). Retrieved August 6, 2017 from https://goo.gl/8sPnVe

Mohammadpur, B., \& Ghafournia, N. (2015). An Elaboration on the Effect of Reading Anxiety on Reading Achievement. English Language Teaching, 8(7), 206-215. Retrieved August 6, 2017 from https://goo.gl/rbzLgM

Muhlis, A. (2017). Foreign language reading anxiety among Indonesian EFL senior high school students. ENGLISH FRANCA: Academic Journal of English Language and Education, 1(1), 19-44. Retrieved September 21, 2017 from https://goo.gl/ZzniW8

Navarro, J. D., Garbin, Z. Z., Agena, E. M., \& Garcia, O. B. (2015). Maritime Students' English Proficiency and Their Feedback on Instructional Materials. Asia Pacific Journal of Maritime Education, 1(1), 1-1. Retrieved August 6, 2017 from https://goo.gl/rj2WSU

Ntereke, B. B., \& Ramoroka, B. T. (2017). Reading competency of first-year undergraduate students at University of Botswana: A case study. Reading \& Writing-Journal of the Reading Association of South Africa, 8(1), 1- 
11. Retrieved August 6, 2017 from https://goo.gl/BeM5a7

Paige, D. D., \& Magpuri-Lavell, T. (2011). Unpacking adolescent literacy skills in a high-poverty, urban high school. In T. Morrison, L. Martin, M. Boggs, \& S. Szabo, (Eds.), Literacy promises: The thirty-third yearbook, a double peer reviewed publication of the Association of Literacy Educators and Researcher: Vol. 33, (pp. 219-236). Association of Literacy Educators and Researchers: Corpus Christi, TX.

Paige, D. D., \& Magpuri-Lavell, T. (2014). Reading fluency in the middle and secondary grades. International Electronic Journal of Elementary Education, 7(1), 83-95. Retrieved February 11, 2018 from https://goo.gl/CUaNWo

Piccolo, L. R., Giacomoni, C. H., Julio-costa, A., Oliveira, S., Zbornik, J., Haase, V. G., \& Salles, J. F. (2017). Reading anxiety in L1: Reviewing the concept. Early Childhood Education Journal, 45(4), 537-543. Retrieved August 6, 2017 from https://goo.gl/7aaGMi

Polit, D.F. and Hungler, B.P. 2013. Essentials of Nursing Research: Methods, Appraisal, and Utilization $\left(8^{\text {th }}\right.$ Edition ed.). Philadelphia: Wolters Kluwer/Lippincott Williams and Wilkins

Rajab, A., Zakaria, W. Z. W., Rahman, H. A., Hosni, A. D., \& Hassani, S. (2012). Reading anxiety among second language learners. Procedia-Social and Behavioral Sciences, 66, 362-369. Retrieved August 6, 2017 from https://goo.gl/TsPnzo

Rasinski, T. (2014). Fluency matters. International Electronic Journal of Elementary Education, 7(1), 3-12. Retrieved July 15, 2017 from https://goo.gl/Efhaa1

Rasinski, T. V., Padak, N. D., McKeon, C. A., Wilfong, L. G., Friedauer, J. A., \& Heim, P. (2005). Is reading fluency a key for successful high school reading? Journal of Adolescent \& Adult Literacy, 49(1), 22-27. Retrieved January 11, 2018 from https://goo.gl/gsQEmd

Readability Formulas. 2017. Flesch - Kinkaid Reading Ease https://goo.gl/BwixTP

Sabti, A. A., Mansor, Y. T. M. B. T., Altikriti, M. Q., Abdalhussein, H. F., \& Dhari, S. S. (2016). Gender Differences and Foreign Language Reading Anxiety of High School Learners in an Iraqi EFL Context. International Journal of Applied Linguistics and English Literature, 5(5), 208-214. Retrieved August 6, 2017 from https://goo.gl/U72XZT

Saito, Y., Garza, T., \& Horwitz, E. K. (1999). Foreign language reading anxiety. The Modern Language Journal. $83,202-218$

Sari, W. P. (2018). The Relationship Between Reading Anxiety and Reading Strategy Used by Efl Student Teachers. Edukasi: Jurnal Pendidikan dan Pengajaran, 4(2), 1-9. Retrieved February 1, 2018 from https://goo.gl/r9TsY7

Schwanenflugel, P. J., Westmoreland, M. R., \& Benjamin, R. G. (2015). Reading fluency skill and the prosodic marking of linguistic focus. Read. Writ. 28, 9-30. Retrieved January 28, 2018 from https://goo.gl/ZTYuP3

Tsai, C. C. (2013). Exploring the relationships between reading anxiety and reading strategy use among university students in Taiwan. International Journal of English and Education, 2(4), 28-39. Retrieved February 11, 2018 from https://goo.gl/b6zlob

Urquhart, A.H. \& Weir, C. J. 2014. Reading in a Second Language: Process, Product and Practice. Routledge: New York City. Retrieved August 6, 2017 from https://goo.gl/FbBbMR

Wallace, J. N. (2013). Effectiveness and efficiency of reading error correction procedures on the reading accuracy, reading fluency, and reading comprehension of fourth grade students (Order No. 3609730). Available from ProQuest Central. (1502876639). Retrieved January 28, 2018 from https://goo.gl/nVQuhD

Zhao, A., Guo, Y., \& Dynia, J. (2013). Foreign language reading anxiety: Chinese as a foreign language in the United States. The Modern Language Journal, 97(3), 764-778. Retrieved August 6, 2017 from https://goo.gl/1D3peL

Zhou, J. (2017). Foreign language reading anxiety in a chinese as a foreign language context. Reading in a Foreign Language, 29(1), 155-173. Retrieved January 28, 2018 from https://goo.gl/qiFwma

Zoghi, M. (2012).An instrument for EFL reading anxiety: Inventory construction and preliminary validation. The Journal of ASIA TEFL, 9(1), 31\&56. 


\section{Appendix A}

Reading Anxiety Questionnaire (Saito et al., 1999).

Direction: The following statements concern the situation of foreign language reading anxiety. Please rate these statements to indicate how you feel or think personally. Please use the following scale in choosing your answer: 4- Strongly Agree; 3 - Agree; 2 - Disagree; 1 - Strongly Disagree.

\begin{tabular}{|c|c|c|c|c|}
\hline \multirow[b]{2}{*}{ Indicators } & \multicolumn{4}{|c|}{ Responses } \\
\hline & 4 & 3 & 2 & 1 \\
\hline 1. I get upset when I am not sure whether I understand what I am reading in English. & & & & \\
\hline $\begin{array}{l}\text { 2. When reading English, I often understand the words but still I cannot quite understand what } \\
\text { the author is saying. }\end{array}$ & & & & \\
\hline 3. When I am reading, I get so confused I cannot remember what I am reading. & & & & \\
\hline 4. I feel intimidated whenever I see a whole page of English in front of me. & & & & \\
\hline 5. I am nervous when I am reading a passage in English when I am not familiar with the topic. & & & & \\
\hline 6. I get upset whenever I encounter unknown grammar when reading English. & & & & \\
\hline 7. When reading English, I get nervous and confused when I do not understand every word. & & & & \\
\hline 8. It bothers me to encounter words I cannot pronounce while reading English. & & & & \\
\hline 9. I usually end up translating word by word when I am reading English. & & & & \\
\hline $\begin{array}{l}\text { 10. By the time I get past the funny letters and symbols in English, it is hard to remember what } \\
\text { I am reading about. }\end{array}$ & & & & \\
\hline 11. I am worried about all the new symbols I have to learn in order to read English. & & & & \\
\hline 12. I enjoy reading English. & & & & \\
\hline 13. I feel confident when I am reading in English. & & & & \\
\hline 14. Once I get used to it, reading English is not so difficult. & & & & \\
\hline 15. The hardest part of learning English is learning to read. & & & & \\
\hline 16. I would be happy just to learn to speak English rather than having to learn to read as well. & & & & \\
\hline $\begin{array}{l}\text { 17. I do not mind reading to myself, but I feel very uncomfortable when I have to read English } \\
\text { aloud. }\end{array}$ & & & & \\
\hline 18. I am satisfied with the level of reading ability in English that I have achieved so far. & & & & \\
\hline 19. English culture and ideas seem very foreign to me. & & & & \\
\hline 20. You have to know so much about English history and culture in order to read English. & & & & \\
\hline
\end{tabular}

\section{Appendix B}

MULTIDIMENSIONAL SCALE FOR READING FLUENCY (Rasinski, 2004)

\begin{tabular}{|c|c|c|c|c|c|}
\hline $\begin{array}{l}\text { Reader } \\
\text { Fluency Area }\end{array}$ & 4 & 3 & 2 & 1 & Score \\
\hline $\begin{array}{l}\text { Accuracy, } \\
\text { Expression } \\
\text { and Volume }\end{array}$ & $\begin{array}{l}\text { Reads with good } \\
\text { expression and } \\
\text { enthusiasm throughout } \\
\text { the text. Varies } \\
\text { expression and volume } \\
\text { to match his or her } \\
\text { interpretation of the } \\
\text { passage. Pronunciation } \\
\text { of words is perfect. }\end{array}$ & $\begin{array}{l}\text { Makes text sound like } \\
\text { natural language throughout } \\
\text { the better part of the } \\
\text { passage. Occasionally slips } \\
\text { into expressionless reading. } \\
\text { Voice volume is generally } \\
\text { appropriate throughout the } \\
\text { text. Makes } 1 \text { - } 3 \text { errors in } \\
\text { pronunciation }\end{array}$ & $\begin{array}{l}\text { Begins to use voice to } \\
\text { make text sound like } \\
\text { natural language in } \\
\text { some in areas of the text } \\
\text { but not in others. Focus } \\
\text { remains largely on } \\
\text { pronouncing the words. } \\
\text { Still reads in a quiet } \\
\text { voice. Makes } 4-6 \\
\text { errors in reading. }\end{array}$ & $\begin{array}{l}\text { Reads words as if } \\
\text { simply to get them out. } \\
\text { Little sense of trying to } \\
\text { make text sound like } \\
\text { natural language. Tends } \\
\text { to read in a quiet voice; } \\
\text { Makes } 7 \text { and above } \\
\text { errors in pronunciation }\end{array}$ & \\
\hline Phrasing & $\begin{array}{l}\text { Generally reads with } \\
\text { good phrasing, mostly in } \\
\text { clause and sentence } \\
\text { units, with adequate } \\
\text { attention to expression. }\end{array}$ & $\begin{array}{l}\text { Reads with a mixture of run- } \\
\text { ons, mid-sentence pauses for } \\
\text { breath, and some } \\
\text { choppiness; reasonable } \\
\text { stress and intonation. }\end{array}$ & $\begin{array}{l}\text { Frequently reads in } \\
\text { two- and three-word } \\
\text { phrases, giving the } \\
\text { impression of choppy } \\
\text { reading; improper stress } \\
\text { and intonation fail to } \\
\text { mark ends of sentences } \\
\text { and clauses. }\end{array}$ & $\begin{array}{l}\text { Reads in monotone with } \\
\text { little sense of phrase } \\
\text { boundaries; frequently } \\
\text { reads word-by-word }\end{array}$ & \\
\hline
\end{tabular}




\begin{tabular}{|c|c|c|c|c|}
\hline Smoothness & $\begin{array}{l}\text { Generally reads } \\
\text { smoothly with some } \\
\text { breaks, but resolves } \\
\text { word and structure } \\
\text { difficulties quickly, } \\
\text { usually through self- } \\
\text { correction. }\end{array}$ & $\begin{array}{l}\text { Occasionally breaks smooth } \\
\text { rhythm because of } \\
\text { difficulties with specific } \\
\text { words and/or structures. }\end{array}$ & $\begin{array}{l}\text { Experiences several } \\
\text { "rough spots" in text } \\
\text { where extended pauses } \\
\text { or hesitations are more }\end{array}$ & $\begin{array}{l}\text { Makes frequent } \\
\text { extended pauses, } \\
\text { hesitations, false starts, } \\
\text { sound-outs, repetitions, } \\
\text { and/or multiple } \\
\text { attempts frequent and } \\
\text { disruptive. }\end{array}$ \\
\hline Pace & $\begin{array}{l}\text { Consistently reads at } \\
\text { conversational pace; } \\
\text { appropriate rate } \\
\text { throughout reading. }\end{array}$ & $\begin{array}{l}\text { Reads with an uneven } \\
\text { mixture of fast and slow } \\
\text { pace. }\end{array}$ & moderately & $\begin{array}{l}\text { Reads slowly and } \\
\text { laboriously. }\end{array}$ \\
\hline \multicolumn{5}{|l|}{ Total } \\
\hline
\end{tabular}

\section{Appendix D}

Oral Reading Fluency Material

Direction: Read the passage orally. Be guided by the multidimensional fluency rubric:

National strength can only be built on character. A nation is nothing more nor less than its citizenry. It is the people that make up the nation and, therefore, it cannot be stronger that its component parts. Their weakness is its failings, their strength its power. Show me a people composed of vigorous, sturdy individuals, of men and women healthy in mind and body; courteous, brave industrious, self-reliant; purposeful in thought as well as in action; imbued with sound patriotism and profound sense of righteousness; with high social ideals and a strong moral fiber; and I will show you a great nation, a nation that will not be submerged, a nation that will emerge victorious from the trials and bitter strifes of a distracted world, a nation that will live forever, sharing that common task of advancing the welfare and promoting the happiness of mankind. We are engaged in the epic task of building our nation, to live and flourish, not for a day but for all time. We must find the flaws, if there be any, in our concept of individual and community life, as well as in our character, and proceed at once to remedy them. I have an abiding faith in our people. I know that they have all the faculties needed to become a powerful and enlightened nation. The Filipino is not inferior to any man of any race. His physical, intellectual, and moral qualities are as excellent as those of the proudest stock of mankind. - Manuel L. Quezon ("The Policies and Achievement of the Government and Regeneration of the Filipino")

\section{Curriculum Vitae}

\section{Personal Data}

Name: Jane Charity Estrada-Madronero

Place of Birth: 54-C Triunfo, Ozamiz City

Date of Birth: July 27, 1993

Office Address: Ozamiz City National High School, Ozamiz City

Civil Status: Single

Father: Joseph R. Estrada

Mother: Catherine A. Estrada

\section{Education}

Graduate: Master of Arts in Education, Major in English Language Teaching, Misamis University, Ozamiz City April 2018

\section{College: Bachelor of Secondary Education Major in English}

Holy Angel University, Angeles City

April 2013

\section{Secondary: Geronima Cabrera National High School}

Riverside, Kolambugan Lanao del Norte

April 2009 
Elementary: Titunod Elementary School Titunod, Kolambugan Lanao del Norte, March 2005

Professional Eligibility: Professional Teacher - Secondary Level September 29, 2013

\section{Work Experiences}

June 2016 - Present:

Secondary School Teacher III Ozamiz City National High School Bernad St., Lam-an, Ozamiz City

October 2014 - June 2016

Secondary School Teacher I/ Abot-Alam Teacher, Alternative Learning System, Division of Ozamiz City

May 2013 - March 2014

High School Teacher, L’Altra Montessori School, Inc., Villasol Subdivision, Angeles City

\section{Seminars/Trainings Attended}

May 20 - June 10, 2016

Regional Mass Training for Grade 11 Teachers Misamis Oriental General Comprehensive High School, Cagayan de Oro City.

December 11 - December 13, 2015

International Training Writeshop for English Teachers Plaza Beatrice, Ozamiz City.

\section{Copyrights}

Copyright for this article is retained by the author(s), with first publication rights granted to the journal.

This is an open-access article distributed under the terms and conditions of the Creative Commons Attribution license (http://creativecommons.org/licenses/by/4.0/). 